\title{
Substantiation and the range of application of a new method for heat transfer prediction in condensing inside plain tubes
}

\author{
Volodymyr Rifert ${ }^{1}$, \\ Volodymyr Sereda ${ }^{2}$, \\ Vadim Gorin ${ }^{1}$, \\ Peter Barabash ${ }^{1}$, \\ Andrii Solomakha ${ }^{1}$ \\ ${ }^{1}$ National Technical University \\ of Ukraine "Igor Sikorsky Kyiv Polytechnic Institute" \\ Politehnichna 6, \\ 03056 Kyiv, Ukraine \\ ${ }^{2}$ National University of Water \\ and Environmental Engineering \\ Soborna 11, \\ 33028 Rivne, Ukraine \\ Email:v.v.sereda@nuwm.edu.ua
}

Since the first work of Tepe and Mueller [1] and until now, there have been published hundreds of studies with the results of heat transfer investigations in vertical and horizontal tubes with vapour condensing of various liquids. Dozens of methods and formulae based both on the results of the theoretical research and on the experimental data have been proposed.

The existence of more than $50 \%$ discrepancy in different experimental data and various empirical and theoretical relationships is shown. Thus, the absence of both substantiation of different methods and explanations of methods disagreement both between themselves and with different experiments is noted. Also, there are often no remarks concerning boundaries for the use of proposed relationships.

There is proposed a simple semi-empirical correlation for heat transfer prediction in condensing inside the plain tubes at the annular and intermediate flow of the phases. This correlation is based on the nature of film condensation process and on the specific features of the results of theoretical solutions. The range of application of complexes, which determine the heat transfer process, is also substantiated.

Good convergence of the new method with the experimental data on condensation of steam, carbon dioxide, hydrocarbon refrigerants and other various fluids inside horizontal and vertical tubes is shown.

Keywords: film condensation, heat transfer, plain tube

\section{INTRODUCTION}

The interest to investigate the hydrodynamics and heat transfer in condensing inside tubes is always relevant due to the demand for improvement of various heat exchangers design, particu- larly in the evaporative systems of thermal desalinating plants, air conditioning systems, safety systems of reactors, heaters of power plants and condensers of cooling equipment. It is very important to know the exact values of condensation heat transfer coefficients when their 
value is close to heat transfer from the cooling side.

Since the publication of the first work of Tepe and Mueller [1] and till now, there have been published hundreds of researches on condensation inside plain tubes and channels. Reviews of some of these researches were carried out by Rifert et al. [2, 6], Garcia-Valladares [3], Kandlikar et al. [4], Dalkilic and Wongwises [5]. Also, there are good reviews in numerous dissertations, starting from the first one of Royal [7] to one of the recent of Macdonald [8]. However, in most reviews, the list of ten-twenty works with a brief description of the objects and findings of the cited authors, investigations are given without their critical analysis. In addition, there is no discussion on the limitations of performed investigations, the shortcomings of the proposed calculation methods, as well as there is no substantiation for new experiments. In most researches, the authors compare their own results with those of various theoretical and empirical calculation methods without any substantiation of their choice. In most cases, new correlations for heat transfer prediction are also proposed without any substantiation. Rifert et al. [6] noted a different degree of convergence of the same correlations for heat transfer calculation by different authors. In addition, it is shown that the accuracy of heat transfer prediction in theoretical solutions depends on the knowledge of shear stress or friction coefficient for which there have been no correct equations up to now.

A new correlation for heat transfer prediction in condensing inside tubes is proposed in this paper. This correlation is obtained by improving the existing semi-empirical relationships using the results of theoretical solutions for the laminar and turbulent flow of a condensate film under the influence of interfacial shear stress $\tau_{w}$.

\section{ANALYSIS OF THEORETICAL SOLUTIONS}

The first theoretical solution for heat transfer prediction during film condensation under the influence of vapour velocity is made by Nusselt [9]. In the dimensionless form, Nusselt's solution takes the form:

$$
N u_{f}=0.5\left(C_{f} F r_{l} / R_{f}\right)^{0.5}
$$

where $N u_{f}=\alpha / \lambda_{l}\left(v_{l}^{2} / g\right)^{2 / 3}$ is film Nusselt number.

Equation (1) is used in many works for heat transfer coefficients definition in vapour condensing inside tubes. The main problem in determining $N u_{f}$ by (1) is the correct estimation of the friction coefficient $C_{f}$

There are several solutions for heat transfer prediction under laminar and turbulent flow of a condensate film in vertical and horizontal tubes at annular phase flow. Particularly, Bae et al. [10] and Traviss et al. [11] presented the results of their solutions in a dimensionless form:

$$
N u_{f}=f\left(\beta, R e_{p}, P r_{l}\right),
$$

where $\beta=0.5 C_{f} F r_{l}$ is parameter related to shear stress in the interphase.

Correlation (2) is plotted in [10] for $\mathrm{Pr}_{l}$ numbers from 1 to 5 . As well as in the case of using (1), it is necessary to know the exact value of the friction coefficient $C_{f}$ in a two-phase flow for determining $N u_{f}$ by (2). At low values of $R e_{l}$ (less than 200) and equal values of parameter $\beta$, prediction of $N u_{f}$ numbers by (1) and (2) gives the same results.

Cavallini et al. [12] measured local heat transfer coefficients and pressure drop for condensation of freons R410A, R32, R134a, R125, $\mathrm{R} 236 \mathrm{ea}$. The authors reached general agreement between their experimental data and Kosky and Staub [13] theoretical solution. It should be noted that the results of the calculations by solution [13] are also dependent on the values of $R e_{l}$ and $C_{f}$

Rifert et al. [14] measured local heat transfer coefficients for condensation of steam and R22 inside a horizontal tube by the "thickness wall" method. The authors showed a good convergence of their own experimental data with the calculation by (2), on condition that the friction coefficient $C_{f}$ is determined by the method they proposed. This method allows estimating the influence of the two-phase flow (parameter $\Phi_{v}^{2}$ ) as well as vapour mass suction on interphase (parameter $\left.\Phi_{q}\right)$ on the friction coefficient $C_{f}$ by:

$$
C_{f}=C_{f_{o}} \Phi_{v}^{2} \Phi_{q}
$$

where $C_{f_{0}}=0.079 / R e_{v}^{0.25}$ at $R e_{v}<10^{5}$ or $C_{f_{0}}=0.046 /$ $R e_{v}^{0.2}$ at $R e_{v} \geq 10^{5} ; R e_{v}$ is vapour Reynolds number. 
Parameter $\Phi_{v}^{2}$ is determined by Miyara's [15] equations:

$$
\begin{aligned}
& \Phi_{v}^{2}=1+C X_{t t}^{n}+X_{t t}^{2} \\
& C=21\left[1-\exp \left(1-0.28 B o^{0.5}\right)\right][1- \\
& \left.-0.9 \exp \left(-0.02 F r_{l}^{1.5}\right)\right], \\
& n=1-0.7 \exp \left(-0.08 F r_{l}\right) .
\end{aligned}
$$

Parameter $\Phi_{q}$ is calculated from [16] by:

$$
\Phi_{q}=1+17.5 R e_{v}^{0.25} j
$$

where the suction parameter $j$ can be obtained:

$$
j=q /(r G x) .
$$

Comparison of heat transfer coefficients predicted by the Rifert et al. [14] method with experimental data in condensing propylene, propane, dimethyl ether, isobutene [17] and FC-72 [18] is shown in Figs. 1-2. Good agreement of the experiments with the calculations (divergence within 25\%) proves the correctness of the Rifert et al. [14] method. The practical application of the Rifert et al. [14] method for calculating heat transfer under various condensation parameters is complicated by the necessity of the solution of the dependence (2) given in an implicit form. Solving the equation (2) is possible in two ways. Graphically, using the interpolation of graphs from [10] or numerically. However, the numerical solution (2), presented in $[10,11]$, has a very cumbersome and uncomfortable look for permanent use.

\section{ANALYSIS OF SEMI-EMPIRICAL RELATIONSHIPS}

In our previous work [6] we performed a detailed analysis of existing semi-empirical design methods. In this paper we discus three most well-known semi-empirical correlations. One of them belongs to Ananiev, Boyko and Kruzhilin [19]. The authors think that heat transfer in mix condensing is completely analogous to convective heat transfer in turbulent liquid flow in a tube:

$$
N u_{d}=c \operatorname{Re}_{l o}^{0.8} \operatorname{Pr}_{l}^{0.43}\left[1+x\left(\rho_{l} / \rho_{v}-1\right)\right]^{0.5}
$$

where $R e_{l o}$ is only liquid Reynolds number.

In equation (9) two-phase flow was taken into account by introduction of the following complex $\left[1+x\left(\rho_{l} / \rho_{v}-1\right)\right]^{0.5}$.

As shown in [6], equation 9 is one of the most successful correlations for generalization of experimental data on vapour condensation inside horizontal and vertical tubes in a wide range of $G, x$ and refrigerant physical properties. However, equation (9)does not work in the regime of phase flow, which is close to the stratified one.

Shah [20] suggested a simple method for heat transfer prediction, in which the correlation for one-phase convection in liquid turbulent flow in

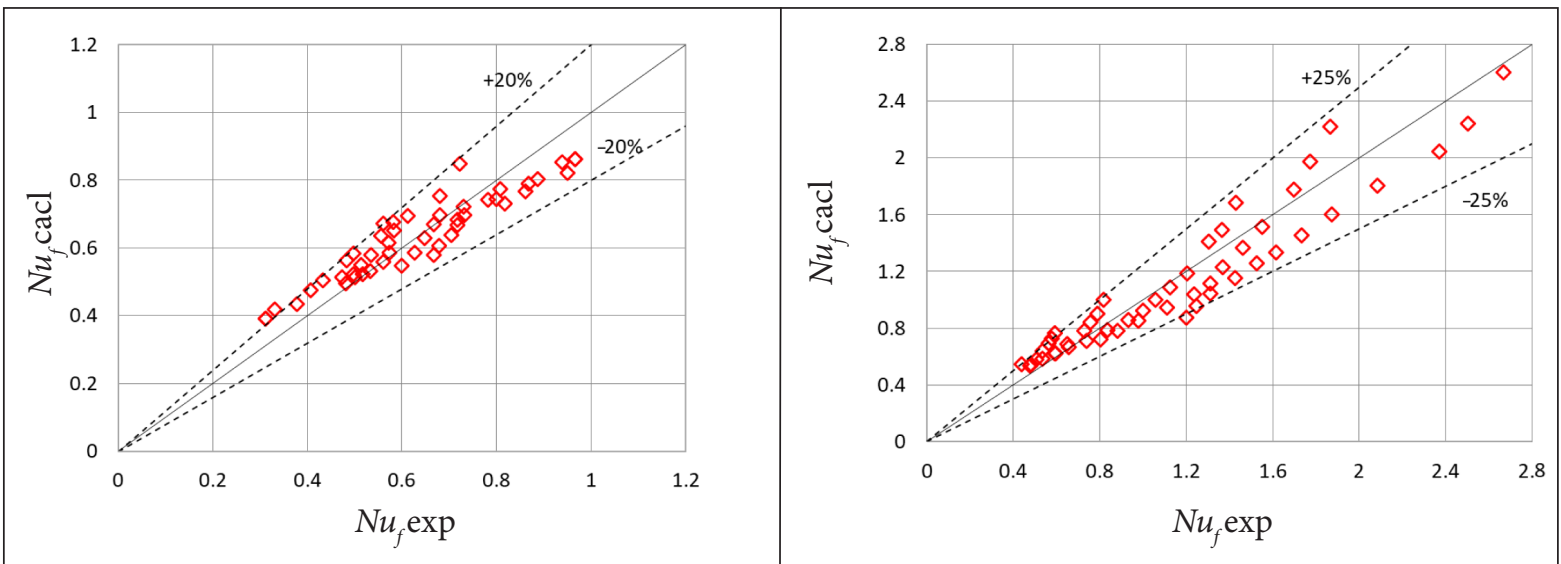

Fig. 1. Comparison of the Park at al. [17] experimental data with the Rifert et al. [14] method

Fig. 2. Comparison of the Lee et al. [18] experimental data with the Rifert et al. [14] method 
tubes is corrected by the function $\Psi=(1-x)^{0.8}+$ $3.8 x^{0.76}(1-x)^{0.04} / p_{r}^{0.38}$, including vapour content $x$ and reduced pressure $p_{r}$ :

$$
\alpha=0.023 \operatorname{Re}_{l o}^{0.8} \operatorname{Pr}_{l}^{0.43}\left(\lambda_{l} / d\right) \Psi
$$

In [21], Shah specified the correlation (10) inserting the new complex $\left(\mu_{l} / 14 \mu_{v}\right)^{n}$ :

$$
\alpha_{\mathrm{I}}=0.023 \operatorname{Re}_{l}^{00.8} \operatorname{Pr}_{l}^{0.43}\left(\mu_{l} / 14 \mu_{v}\right)^{n} \Psi
$$

where $n=0.0058+0.557 p_{r}$

Shah [21] proposed to apply equation (11) for heat transfer prediction if

$$
J_{g} \geq 0.98(Z+0.263)^{-0.62}
$$

where $Z=(1 / x-1)^{0.8} \operatorname{Pr}_{l}^{0.4} ; J_{g}$ is dimensionless vapour velocity.

It should be noted that Borishanskij et al. [22] used reduced pressure $p_{r}$ for heat transfer prediction in condensing earlier than Shah [20]. This fact was mentioned in [23].
In Table 1 it is shown the comparison of the additional complexes from (9) and for condensation of steam [24], methane [25], isobutene [17], freon R22 [14] and freon R245fa [26]. As seen from Table 1, the values of the additional complexes are practically the same (divergence within 25\%). However, Ananiev's et al. correlation (9) is preferred to be used, because in contrast to Shah's formula (11), it has theoretical substantiation and clearer range of application.

The third known semi-empirical equation for heat transfer prediction in condensing inside the horizontal tube was devised by Thome et al. [27]:

$$
N u_{d}=0.0039 f_{i} \operatorname{Re}_{\delta}^{0.7} \operatorname{Pr}_{l}^{0.5},
$$

\begin{tabular}{|c|c|c|c|c|c|c|}
\hline No. & $\begin{array}{l}\text { Work } \\
\text { Fluid }\end{array}$ & $\frac{t_{s}}{p_{r}}$ & $\frac{G}{x}$ & $\frac{R e_{l o}}{P r_{l}}$ & $\left.\left(\mu_{l} / 14 \mu_{v}\right)^{n} \Psi\right)$ & {$\left[1+x\left(\rho_{v}-1\right)\right]^{0.5}$} \\
\hline \multirow{2}{*}{1} & \multirow{2}{*}{$\begin{array}{c}{[24]} \\
\text { steam }\end{array}$} & \multirow{2}{*}{$\frac{189.1}{0.0557}$} & $\frac{213}{0.84}$ & $\frac{19395}{0.95}$ & 9.36 & 10.85 \\
\hline & & & $\frac{405}{0.55}$ & $\frac{48322}{0.95}$ & 7.42 & 8.8 \\
\hline \multirow{2}{*}{2} & \multirow{2}{*}{$\begin{array}{c}{[25]} \\
\text { methane }\end{array}$} & \multirow{2}{*}{$\frac{-107.3}{0.4348}$} & $\frac{200}{0.87}$ & \multirow{2}{*}{$\frac{19342}{1.9}$} & 3.61 & 2.95 \\
\hline & & & $\frac{200}{0.54}$ & & 2.96 & 2.4 \\
\hline \multirow{2}{*}{3} & \multirow{2}{*}{$\begin{array}{l}{[14]} \\
\text { freon } \\
R-22\end{array}$} & $\begin{array}{l}43.5 \\
0.3352 \\
\end{array}$ & $\underline{226}$ & $\frac{28907}{2.4}$ & 4.65 & 3.68 \\
\hline & & $\begin{array}{l}45.5 \\
0.3515\end{array}$ & $\underline{28}$ & $\frac{3669}{2.4}$ & 3.7 & 2.89 \\
\hline \multirow{2}{*}{4} & \multirow{2}{*}{$\begin{array}{c}{[17]} \\
\text { isobutane }\end{array}$} & \multirow{2}{*}{0.1459} & $\frac{200}{0.82}$ & $\frac{13725}{3.9}$ & 6.68 & 5.66 \\
\hline & & & $\frac{100}{0.5}$ & $\frac{6863}{3.9}$ & 5.18 & 4.46 \\
\hline \multirow{2}{*}{5} & \multirow{2}{*}{$\begin{array}{c}{[26]} \\
\text { freon } \\
R-245 f a\end{array}$} & \multirow{2}{*}{$\underline{50} \underline{50940}$} & $\frac{300}{0.95}$ & $\frac{7750}{5.2}$ & 8.37 & 7.92 \\
\hline & & & $\frac{500}{0.5}$ & $\frac{12917}{5.2}$ & 6.11 & 5.79 \\
\hline
\end{tabular}

where

$$
\begin{aligned}
& N u_{d}=\frac{\alpha \delta}{\lambda_{l}}, R_{\delta}=\frac{4 G(1-x) \delta}{(1-\varepsilon) \mu_{l}}, \\
& f_{i}=1+\left(w_{v} / w_{l}\right)^{0.5}\left[\left(\rho_{l}-\rho_{v}\right) g \delta^{2} / \sigma\right]^{0.25} .
\end{aligned}
$$

Table 1. Comparison of the additional complexes from (9) and (11) 
The authors did not support the introduction of correct function $f_{i}$ with any experimental data. This method is often used by researchers to compare with different experiments. It should be mentioned that formula (13) is used for the annular, intermediate and stratified phase flow. As shown in [28], there is a good convergence (about $20 \%$ ) between the experiments on condensation of carbon dioxide inside the horizontal tube of $d=3.42 \mathrm{~mm}$ and $l=3.5 \mathrm{~m}$ at $G=200-800 \mathrm{~kg} /$ $\left(\mathrm{m}^{2} \cdot \mathrm{s}\right)$ with the calculations by equation (13). However, it was also shown in another article [29] that there is the discrepancy in $172 \%$ between the experimental data on condensation of carbon dioxide with similar specification and the data calculated by (13).

\section{SUBSTANTIATION AND THE RANGE OF APPLICATION OF A NEW SEMI- EMPIRICAL CORRELATION}

The analysis of the scientific papers devoted to comparing the experimental data on condensation inside tubes grounded on various methods of calculation shows great differences in the results obtained by different authors. In this case, the differences are observed when using the same methods (dependencies) for calculating heat transfer for both identical and different liquids. The discrepancy in the identical calculation methods for the same substances by different authors reaches up to $100 \%$ or more.

When using theoretical solutions, the main reason for such significant discrepancies is the use of different methods for calculating the friction coefficient $C_{f}$ on the boundary of the phases. At the same time, it is also important to know the limits of applying this or that dependency for its comparison with theoretical solutions. Many empirical correlations are obtained in the narrow ranges of $G, x$, physical properties and therefore they correspond only to specific experimental methods.

The theory of film condensation when influenced by the vapour velocity [10] shows that the $N u_{f}$ number is the function of three parameters $\beta, R e_{p}, P r_{l}$ (see eq. (2)). As can be seen from [10], depending on the value of each of these parameters, the theory predicts a different degree of their effect on heat transfer. For instance, in the region of predominantly laminar or laminar-wave film flow, the effect of $\mathrm{Pr}_{l}$ on $\mathrm{Nu} u_{f}$ number decreases with decreasing $R e_{l}$ up to the complete absence.

The accuracy of calculating $N u_{f}$ number in the region of $\beta$ influence depends on the accuracy of the determination of friction coefficient $C_{f}$ Up till present, there has been no valid methodology for calculating $C_{f}$ For example, Macdonald [8] considers more than 20 formulae for calculating $C_{f}$ None of them has sufficient (within $\pm 25 \%$ ) accuracy when compared to the experiments.

The analysis of the theory [10] shows that for $\beta>10$ (under the influence of vapour velocity on heat transfer) and $P r_{l}=1-3$ under the changes of $R e_{l}$ from $8 \cdot 10^{2}$ to $2 \cdot 10^{4}$, the impact of $R e_{l}$ on $N u_{f}$ can be neglected. Figure 3 shows the influence of

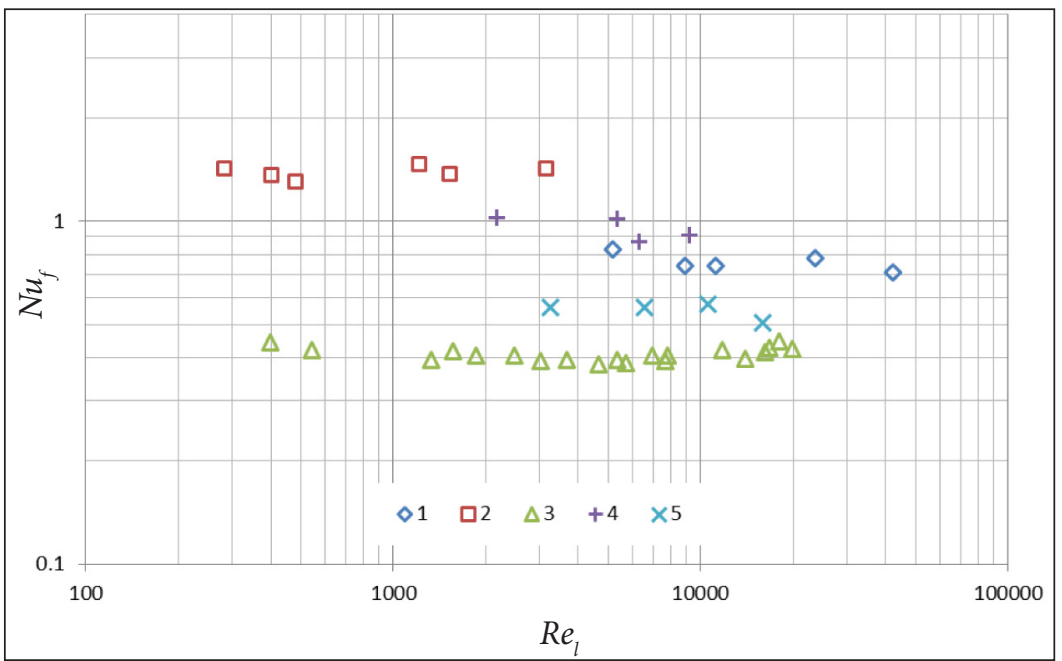

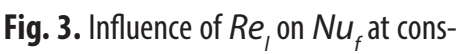
tant values of $\mathrm{Pr}_{1}$ and $\beta: 1$ - data from Boyko et al. [24] for steam at $P r_{1}=0.95$, $\beta=150 ; 2-$ data from Lee et al. [18] for fluid FC-72 at $P r_{1}=8.2, \beta=40 ; 3$ - data from Yu et al. [30], Rifert et al. [14], Park et al. [17], Kwon et al. [31] for freon R22 and from Kim et al. [28] for carbon dioxide at $P r_{1}=2.4, \beta=10 ; 4-$ data from Kim et al. [28] for carbon dioxide at $P r_{1}=2.4$, $\beta=100 ; 5$ - data from Boyko et al. [24] for steam at $P r_{1}=0.95, \beta=100$ 
$R e_{l}$ on $N u_{f}$ at constant values of $\operatorname{Pr}_{l}$ and $\beta$, based on the experimental data of different authors. As Fig. 3 displays, only at high vapour velocities $(\beta$ more than 100) there is an insignificant decrease of $N u_{f}$ with an increase of $R e_{l}$. The boundaries for $R e_{l}$ variations from $8 \cdot 10^{2}$ to $2 \cdot 10^{4}$ are characteristic of all freons (R22, R134a, R125, R32, R410A), hydrocarbons (propane, isobutane, propylene, dimethyl ether) and carbon dioxide at $G$ from 200 to $800 \mathrm{~kg} / \mathrm{m}^{2} \mathrm{~s}$ and at $\beta$ more than 10. These particularities of theoretical calculations [10] became the basis to generalize the data on the local heat transfer coefficients of many works on condensation inside both vertical and horizontal tubes by the formula $N u_{f}=f\left(F r_{l}, P r_{l}\right)$.

The absence of the friction coefficient in this dependence (it is used in the theoretical solutions $[10,11]$ to determine the parameter $\beta$ ) can be explained as follows. The number $\mathrm{Fr}_{l}$ increases along with increasing $w_{v}^{2}$, and the value $C_{f}$ in this case (if the influence of $q / r G$ is ignored) proportionally decreases $w_{v}^{2-0.25}$ depending on the value $R e_{v}$. For this reason, the influence of vapour velocity on $F r_{l}$ is much greater than the influence of vapour velocity on the friction coefficient.

We summarized the following data: Park et al. [17] data on condensation of isobutene, dimethyl ether, propane, propylene; Kim et al. [28] data on condensation of carbon dioxide; Cavallini et al. [12] data on condensation of freons
R134a, R125, R32, R410A, R236ea; data on steam condensation inside horizontal [24] and vertical [32] tubes; Ghim and Lee [26] data on condensation of organic fluids R245fa, NOVEC649 and HFE-7000. Of all the experiments, the data were processed at such values of mass velocities $G$ and vapour contents $x$ when, according to the recommendation of [27], there was observed an annular or intermediate regime. This usually occurs when $\beta>5$ and when $F r_{1}>500$. In Fig. 4 the data of authors mentioned above are generalized by such correlation:

$$
N u_{f}=0.0144 \mathrm{Fr}_{l}^{0.36} \mathrm{Pr}_{l}^{0.43} .
$$

As seen in Fig. 5, equation generalizes all experimental data with the error less than $25 \%$.

In order to confirm the accuracy of the new method, its verification is performed with experimental data from the works of the following scientists: concerning the condensation of freon R-134a in a vertical tube - Dalkilic et al. [33]; fluid FC-72 - Lee et al. [18]; propane - Macdonald [8]; methane - Zhuang et al. [25] and carbon dioxide - Peihua Li et al. [34]. The results are shown in Fig. 6, which make it evident that the developed method of calculation with an accuracy of $\pm 30 \%$ generalizes all experimental data in the annular and intermediate modes of phase flow.

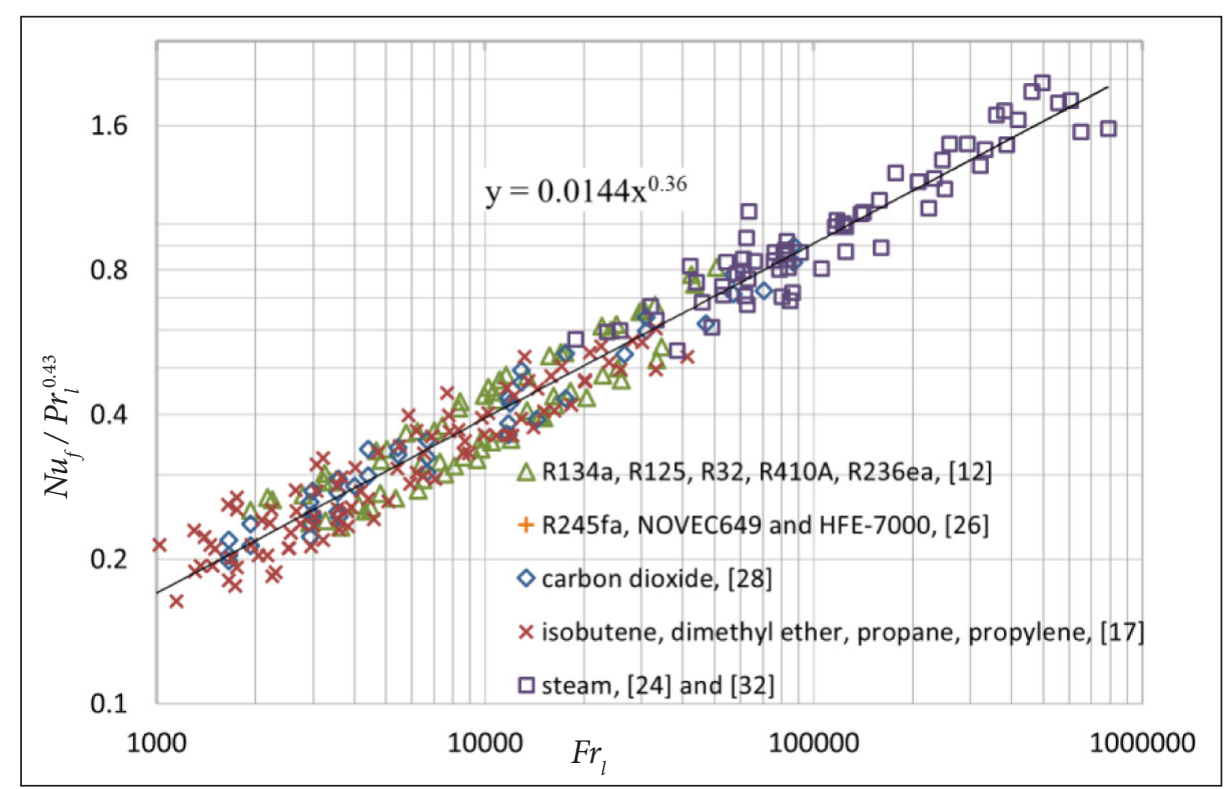

Fig. 4. Approximation of the experimental data of different authors in the form $N u_{f}=f\left(F r_{,}, P_{\mu}\right)$ 


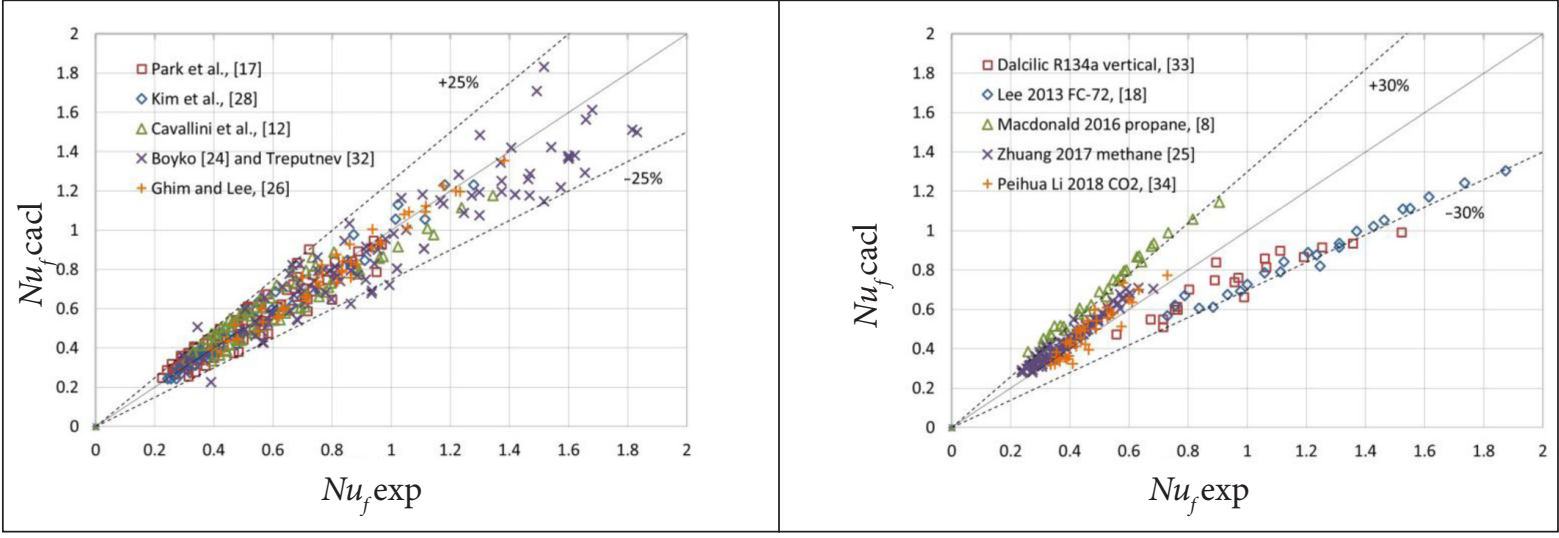

Fig. 5. Calculated vs. experimental heat transfer coefficients: predictions by the proposed method

Fig. 6. Application of the new method to various experimental data

\section{CONCLUSIONS}

The outcomes of our theoretical investigation are the following:

1. There was obtained a new correlation for heat transfer prediction, which is based on the theoretical model of turbulent condensation and can be expressed in the form offered: $N u_{f}=0.0144 \mathrm{Fr}_{l}^{0.36} \mathrm{Pr}_{l}^{0.43}$. This equation generalizes a large number of experimental data on condensation of different refrigerants inside horizontal and vertical tubes.

2. The formula suggested the calculation does not need any correct estimation of phase flow regimes, condensate accumulation and a friction coefficient.

3. The two restrictions should be considered when using the suggested correlation: firstly, $\mathrm{Fr}_{l}$ must be more than 500; secondly, $\beta$ must be more than 5 .

\section{NOMENCLATURE}

Bo - Bond number $\left(=g d^{2}\left(\rho_{l}-\rho_{v}\right) / \sigma\right)$

$C_{f}$ - friction coefficient

$d$-inner diameter of tube, $m$

$d$ - inner diameter of tube, $\mathrm{m}$
$F r_{l}-$ liquid Froude number $\left(=\frac{\tilde{\mathrm{n}}_{v}\left(\tilde{\mathrm{n}}_{l}-\tilde{\mathrm{n}}_{v}\right) w_{v}^{2}}{\tilde{\mathrm{n}}_{l}^{2}\left(v_{l} g\right)^{2 / 3}}\right)$
$G$ - mass velocity, $\mathrm{kg} /\left(\mathrm{m}^{2} \mathrm{~s}\right)$

$g$ - gravitational acceleration, $\mathrm{m} / \mathrm{s}^{2}$

$J_{g}$ - dimensionless vapour velocity

$\left.\stackrel{g}{=} x G /\left[g d \rho_{v}\left(\rho_{l}-\rho_{v}\right)\right]^{0.5}\right)$

$l$ - length of the tube, $\mathrm{m}$

$\mathrm{Nu}$ - Nusselt number

$p_{s}$ - saturated pressure, $\mathrm{Pa}$

Received 1 March 2018

$P_{c r}-$ critical pressure, $\mathrm{Pa}$

$P r$ - Prandtl number

$p_{r}-$ reduced pressure $\left(=\rho_{s} / \rho_{c r}\right), \mathrm{Pa}$

$q$ - heat flux, $\mathrm{W} / \mathrm{m}^{2}$

$r$ - heat of vaporization, $\mathrm{J} / \mathrm{kg}$

$R e_{f}$ - film Reynolds number $\left(\mu=q l /\left(r \mu_{l}\right)\right)$

$R e_{l}$ - liquid Reynolds number $\left(=G(1-x) d / \mu_{l}\right)$

$R e_{l o}$ - only liquid Reynolds number $\left(=G d / \mu_{l}\right)$

$R e_{v}$ - vapour Reynolds number $\left(=G x d / \mu_{v}\right)$

$t_{s}$ - saturated temperature, ${ }^{\circ} \mathrm{C}$

$w$ - velocity, $\mathrm{m} / \mathrm{s}$

$x$ - mass vapor quality

Greek Symbols

$\alpha$ - heat transfer coefficient, $\mathrm{W} /\left(\mathrm{m}^{2} \mathrm{~K}\right)$

$\beta$ - parameter related to shear stress in the interphase

$\delta$ - thickness of the condensate film, $\mathrm{m}$

$\lambda$ - thermal conductivity, $\mathrm{W} /(\mathrm{mK})$

$\mu$ - dynamic viscosity, Pa.s

$v$ - kinematic viscosity, $\mathrm{m}^{2} / \mathrm{s}$

$\rho$ - density, $\mathrm{kg} / \mathrm{m}^{3}$

$\sigma-$ surface tension, $\mathrm{N} / \mathrm{m}$

$\tau_{w}$ - shear stress, $\mathrm{Pa}$

$\Phi_{v}^{2}$ - parameter that takes into account the influence of two-phase flow on shear stress

$\Phi_{q}$ - parameter that takes into account surface suction at the interphase

Subscripts

$d$-dimensionless

$f$ - film

$l-$ liquid

$v$ - vapour

exp - experimental

calc - calculated 


\section{References}

1. Tepe J., Mueller A. Condensation and subcooling inside an inclined tube. Chemical Engineering Progress. 1947. Vol. 43. P. 267-278.

2. Rifert V. Vapor condensation inside horizontal pipes. Journal of Engineering Physics and Thermophysics. 1983. Vol. 44. Iss. 6. P. 700-710.

3. Garcia-Valladares O. Review of in-tube condensation heat transfer correlations for smooth and microfin tubes. Heat Transfer Engineering. 2003. Vol. 24. Iss. 4. P. 6-24.

4. Kandlikar S. G., Garimella S., Li D., Colin S., King M. R. Heat Transfer and Fluid Flow in Minichannels and Microchannels. Elsevier Ltd, Kidlington, Oxford, 2006. 450 p.

5. Dalkilic A., Wongwises S. Intensive literature review of condensation inside smooth and enhanced tubes. International Journal of Heat and Mass Transfer. 2009. Vol. 52, Iss. 15-16. P. 3409-3426.

6. Rifert V., Sereda V. Condensation inside smooth horizontal tubes: Part 1. Survey of the methods of heat-exchange prediction. Thermal Science. 2015. Vol. 19. No. 5. P. 1769-1789.

7. Royal J. H. Augmentation of Horizontal In-Tube Condensation of Steam. PhD Dissertation. Iowa State University, 1975. 386 p.

8. Macdonald M. Condensation of Pure Hydrocarbons and Zeotropic Mixtures in Smooth Horizontal Tubes. Doctoral Dissertation. Georgia Institute of Technology, 2015. $256 \mathrm{p}$.

9. Nusselt W. Die Oberflächenkondensation des Wasserdampfes. Zeitschrift VDI. 1916. Vol. 60. P. 541-546. 568-575.

10. Bae S., Maulbetsch J., Rohsenow W. Refrigerant Forced-Convection Condensation Inside Horizontal Tubes. Report No. DSR-79760-64. Massachusetts Institute of Technology, Cambridge, MA, 1969. $121 \mathrm{p}$.

11. Traviss D., Baron A., Rohsenow W. Forced-Convection Condensation Inside Tubes. Report No. DSR-72591-74. Massachusetts Institute of Technology, Cambridge, MA, 1971. 105 p.

12. Cavallini A., Censi G., Del Col D., DorettI L., Longo G., Rossetto L. Experimental investigation on condensation heat transfer and pressure drop of new refrigerants (R134a, R125, R32,
R410A, R236ea) in a horizontal smooth tube. International Journal of Refrigeration. 2001. Vol. 24. Iss. 1. P. 73-87.

13. Kosky P., Staub F. Local condensing heat transfer coefficients in the annular flow regime. AIChE Journal. 1971. Vol. 17. No. 5. P. 1037-1043.

14. Rifert V., Sereda V., Barabash P., Gorin V. Condensation inside smooth horizontal tubes. Part 2. Improvement of heat exchange prediction. Thermal Science. 2017. Vol. 21. No. 3. P. 1479-1489.

15. Afroz H., Miyara A., Tsubaki K. Heat transfer coefficients and pressure drops during in-tube condensation of CO2/DME mixture refrigerant. International Journal of Refrigeration. 2008. Vol. 31. Iss. 8. P. 1458-1466.

16. Kinney R., Sparrow E. Turbulent flow, heat transfer and mass transfer in a tube with surface suction. ASME Journal of Heat Transfer. 1970. Vol. 92. No. 1. P. 121-131.

17. Park K., Jung D., Seo T. Flow condensation heat transfer characteristics of hydrocarbon refrigerants and dimethyl ether inside a horizontal plain tube. Journal of Multiphase Flow. 2008. Vol. 34. Iss. 7. P. 628-635.

18. Lee H., Mudawar I., Hasan M. Flow condensation in horizontal tubes. International Journal of Heat and Mass Transfer. 2013. Vol. 66. P. 31-45.

19. Ananiev E., Boyko L., Kruzhilin G. Heat transfer in the presence of steam condensation in a horizontal tube. International Heat Transfer Conference 2. Boulder, Colorado, USA. 1961. No. 2. P. 290-295.

20. Shah M. A general correlation for heat transfer during film condensation inside pipes. International Journal of Heat and Mass Transfer. 1979. No. 22. P. 547-556.

21. Shah M. An improved and extended general correlation for heat transfer during condensation in plain tubes, ASHRAE Transactions. 2009. No. 15. P. 889-913.

22. Borishanskij V. Application of thermodynamic similarity method for generalization of experimental data on film-type condensation. Trudy TsKTI, Leningrad. 1975. No. 131 [in Russian].

23. Rifert V. Heat transfer and flow modes of phases in laminar film vapour condensation inside a horizontal tube. International Journal of Heat 
and Mass Transfer. 1988. Vol. 31. Iss. 3. P. 517523.

24. Boyko L. Heat transfer during vapor condensation inside tubes. Heat Transfer in the Elements of Power Plants. 1966. P. 197-212 [in Russian].

25. Zhuang X., Chen G., Zou X., Song Q., Gong M. Experimental investigation on flow condensation of methane in a horizontal smooth tube. International Journal of Refrigeration. 2017. Vol. 78. P. 193-214.

26. Ghim G., Lee J. Condensation heat transfer of low GWP ORC working fluids in a horizontal smooth tube. International Journal of Heat and Mass Transfer. 2017. Vol. 104. P. 718-728.

27. Thome J., Hajal J., Cavallini A. Condensation in horizontal tubes. Part 2: New heat transfer model based on flow regimes. International Journal of Heat and Mass Transfer. 2003. Vol. 46. Iss. 18. P. 3365-3387.

28. Kim Y., Jang J., Hrnjak P., Kim M. Condensation heat transfer of carbon dioxide inside horizontal smooth and microfin tubes at low temperature. Journal of Heat Transfer ASME. 2008. Vol. 131. Iss. 2. Article 021501.

29. Kang P., Heo J., Yun R. Condensation heat transfer characteristics of $\mathrm{CO}_{2}$ in a horizontal smooth tube. International Journal of Refrigeration. 2013. Vol. 36. No. 3. P. 1090-1097.

30. Yu J., Koyama S., Haraguchi H., Momoki S., Ishibashi A. Boiling and condensation of alternative refrigerants in a horizontal smooth tube. Reports of Institute of Advanced Material Study, Kyushu University. 1995. Vol. 9. No. 2. P. 137-154.

31. Kwon J., Ahn Y., Kim M. A modelling of in-tube condensation heat transfer for a turbulent annular film flow with liquid entrainment. International Journal of Multiphase Flow. 2001. Vol. 27. Iss. 5, P. 911-928.

32. Treputnev V. V. Investigation of Heat Transfer and Hydraulic Resistance during Steam Condensation in Smooth and Profiled Tubes. PhD Dissertation, State Research Energy Institute of G. M. Krzhizhanovsky, Moscow, Russia, 1979. 183 p. [in Russian].

33. Dalkilic A. S., Aktas M., Acikgoz O., Wongwises S. A review of recent empirical correlations for the calculation of determination of R134a's convective heat transfer coefficient in vertical condensers. International Communications in Heat and Mass Transfer. 2015. Vol. 69. P. 41-50.

34. Peihua L., Chen J. J. J., Norris S. Flow condensation heat transfer of $\mathrm{CO}_{2}$ in a horizontal tube at low temperatures. Applied Thermal Engineering. 2018. Vol. 130. P. 561-570.

Volodymyr Rifert, Volodymyr Sereda, Vadim Gorin, Peter Barabash, Andrii Solomakha

\section{NAUJOJO ŠILUMOS MAINŲ PROGNOZAVIMO METODO PAGRINDIMAS IR NAUDOJIMO SRITIS VYKSTANT KONDENSACIJAI VAMZDŽIUOSE}

\section{Santrauka}

Nuo pirmojo J. Tepe ir A. Muellerio [1] darbo paskelbti šimtai tyrimų, kuriuose buvo pateiktos šilumos perdavimo vertikaliuose ir horizontaliuose vamzdeliuose su įvairių skysčių garų kondensacija tyrimų išvados. Pasiūlyta daugybè metodų ir formulių, pagrịstų tiek teorinių tyrimų rezultatais, tiek eksperimentiniais duomenimis.

Parodyta, kad eksperimentinių duomenų ir ịvairių empirinių bei teorinių skaičiavimų neatitiktys siekia per $50 \%$. Trūksta skirtingų metodų pagrịstumo ir metodų neatitikimų tiek tarpusavyje, tiek ir su skirtingais eksperimentais paaiškinimų. Be to, dažnai nepateikiama pastabų dèl pasiūlytų sąsajų naudojimo ribų.

Pasiūlyta paprasta pusiau empirine koreliacija šilumos perdavimui ir kondensacijai paprastų vamzdžių viduje žiediniame ir tarpiniame fazių srautuose prognozuoti. Ši koreliacija pagrịsta plèvelès kondensacija ir teorinių sprendimų rezultatų specifika. Taip pat pagrịsta šilumos perdavimo taikymo sritis.

Parodyta gera naujojo metodo konvergencija su garų, anglies dvideginio, angliavandenilių aušalų ir kitų ivvairių skysčių, esančių horizontaliuose ir vertikaliuose vamzdeliuose, kondensacijos eksperimentiniais duomenimis.

Raktažodžiai: plèvelinè kondensacija, šilumos perdavimas, paprastas vamzdis 